\title{
EFEKTIVITAS PENERAPAN INTERNET MARKETING 4.0 TERHADAP PEMESANAN TIKET TRAVEL PEKANBARU DURI DUMAI
}

\author{
1) Fauzan Azim, ${ }^{2)}$ Ikhbal Akhmad, ${ }^{3)}$ Hadi Purwanto, ${ }^{4)}$ Khairul Anshari, ${ }^{5)}$ Sunanto \\ 1,4)Program Studi Pendidikan Vokasional Teknik Elektronika, Universitas Muhammadiyah Riau \\ ${ }^{2)}$ Program Studi Manajemen, Universitas Muhammadiyah Riau \\ ${ }^{3)}$ Program Studi Pendidikan IPA, Universitas Muhammadiyah Riau \\ ${ }^{5)}$ Program Studi Teknik Informatika, Fakultas Ilmu Komputer, Universitas Muhammadiyah Riau \\ 1,2,3,4,5) Jl. Tuanku Tambusai Ujung, Simpang Komersil Arengka, Kota Pekanbaru, Riau 28290 \\ E-mail : ')fauzanazim@umri.ac.id
}

\begin{abstract}
ABSTRAK
Penelitian ini dilaksanakan di PT. Jasa Mulya Trans Gemilang, perusahaan yang bergerak dibidang layanan jasa transportasi antar jemput alamat dengan rute pekanbaru duri dumai. PT. Jasa Mulya Trans Gemilang memiliki dua buah website yang cukup baik di search engine Google, Bing dan Yahoo. PT. Jasa Mulya Trans Gemilang juga melakukan Promosi Iklan melalui Media Sosial dan Iklan Berbayar Google Ads yang sudah berjalan cukup lama. Dan sampai saat penelitian ini dilakukan belum ada pengukuran seberapa baik tingkat Efektivitas Internet Marketing yang telah berjalan di PT. Jasa Mulya Trans Gemilang. Pengukuran Efektivitas Sebuah Program Internet Marketing sangat diperlukan untuk bahan pertimbangan dan strategi promosi yang dapat dilakukan untuk kedepanya oleh perusahaan. Dan untuk mengukur sebuah Efektivitas Pemanfaatan Internet Marketing salah satunya dapat memanfaatkan Model EPIC. Pada Model EPIC terdapat empat Variabel yang diteliti untuk mengukur efektivitas yaitu Empathy, Persuasion, Impact dan Communication. Responden dalam penelitian ini adalah masyarakat kota Pekanbaru dan sekitarnya yang memesan tiket travel dengan tujuan daerah Duri sekitarnya, dan Kota Dumai. Setelah dilaksanakan penelitian ini maka didapatkan hasil yang membuktikan bahwa tingkat efektivitas Penerapan Internet Marketing terhadap pemesanan tiket travel Pekanbaru Duri Dumai yang diukur dalam empat Dimensi EPIC yang masing-masing bernilai sebagai berikut; emphaty bernilai 4,09, persuasion bernilai 4,11, impact bernilai 3,88, dan communication bernilai 3,99. Dari keempat Dimensi EPIC tersebut maka didapatkan hasil rata-rata Model EPIC atau EPICrate 4,02 yang dapat di interpretasikan pada skala efektif, Artinya dalam penelitian ini, Penerepaan Internet Marketing di PT. Jasa Mulya Trans Gemilang melalui internet yang terdiri dari Website, Media Sosial dan Google Ads dapat dinyatakan Efektif.
\end{abstract}

Kata Kunci: efektivitas, internet marketing, marketing 4.0, tiket, travel.

\begin{abstract}
This research was conducted at PT. Jasa Mulya Trans Gemilang, a company engaged in transportation services by routes of Pekanbaru-Duri-Dumai. PT. Jasa Mulya Trans Gemilang has two websites that are quite good on the search engines of Google: Bing and Yahoo. It also carries out Advertising Promotions through Social Media and Google Ads which have been running for a long time and until the time this research was conducted, there was no measurement of how well the effectiveness of Internet Marketing that has been running at PT. Jasa Mulya Trans Gemilang. Measuring the Effectiveness of an Internet Marketing Program is indispensable for consideration and promotional strategies that can be carried out for the future by the company. One of the ways to measure the effectiveness of Internet Marketing Utilization was the EPIC Model. In the EPIC Model, there were four variables which were investigated to measure effectiveness, namely Empathy, Persuasion, Impact and Communication. Respondents in this study were the people of Pekanbaru and its surroundings who ordered travel tickets with destination of Duri and Dumai Cities. After conducting this research, it was obtained that the effectiveness levels of Internet Marketing Application of travel ticket reservations for Pekanbaru-Duri-Dumai which was measured in four EPIC dimensions were as follows: the value of Emphaty was 4.09, the Persuasion was 4.11, the Impact was 3.88, and the Communication was 3.99. From the four EPIC dimensions, the average result of the EPIC Model or EPICrate was 4.02 that could be interpreted on an effective scale. This means that in this research, the implementation of Internet Marketing at PT. Jasa Mulya Trans Gemilang through the internet consisting of Website, Social Media and Google Ads was effective.
\end{abstract}

Keyword: effectiveness, internet marketing, marketing 4.0, tickets, travel. 


\section{PENDAHULUAN}

Perkembangan teknologi saat ini merupakan bagian dari Revolusi Industri 4.0. salah satu yang menandai lahirnya Revolusi Industri 4.0 adalah Internet of Think (IoT). Secara sederhana Internet of Think adalah konsep yang pada intinya menghubungan perangkat apapun dengan tombol on off ke Internet. Perangkat yang dimaksud misalnya ponsel, mesin pembuat kopi, mesin cuci, lampu, perangkat yang dikenakan tubuh dan semacamnya.[1]

Tahun 2007, Jumlah pengguna Internet di Indonesia hanya 20 juta pengguna. Saat ini kita memiliki lebih dari 130 juta pengguna internet. Jumlah ini termasuk peringkat keenam di Dunia. Pertumbuhan pengguna Internet di Indonesia mencapai lebih $20 \%$ per tahun. Angka ini kian tahun kian bertambah. Karena itu kesempatan menjadikan dan mencapai pengguna internet sebagai target pasar sangatlah besar[2].

Marketing pada saat ini telah masuk ke era Marketing 4.0 merupakan pendekatan pemasaran yang mengkombinasikan interaksi online dan interaksi offline antara perusahaan dengan pelanggan. Strategi mempromosikan produk melalui perangkat elektronik dan internet ini disebut dengan Digital Marketing. Dan bagian khusus yang mempromosikan produk di internet seperti website dan media sosial (Instagram, facebook, twitter, line, whatsapp dan lainya) disebut dengan Internet Marketing.

Di Pekanbaru sendiri pemanfatan Internet marketing sudah cukup baik, Usaha Mikro Kecil dan Menengah (UMKM) hingga perusahaan besar, turut berperan aktif memanfaatkan Internet Marketing sebagai sarana promosi. Salah satu perusahaan di Pekanbaru yang memanfaatkan Internet marketing adalah PT. Jasa Mulya Trans Gemilang. PT. Jasa Mulya Trans Gemilang merupakan perusahaan layanan transportasi angkutan penumpang Antar Jemput Alamat, yang telah berjalan sejak tahun 2018 dengan rute Pekanbaru Duri Dumai.

Dari pengamatan penulis, saat ini PT. Jasa Mulya Trans Gemilang telah temasuk kedalam perusahaan jasa transportasi melek teknologi melalui platform internet sudah cukup bervariasi. PT Jasa Mulya Trans Gemilang telah memiliki dua buah website yang sudah cukup baik dan sudah masuk dalam halaman pertama search engine terpopuler diantaranya Google, Bing, dan Yahoo. PT. Jasa Mulya Trans Gemilang juga memiliki akun media sosial utama yaitu Facebook dan Instagram. Dan pengelolaan media sosial di PT Jasa Mulya Trans Gemilang seperti Instagram dan Facebook sudah dikelola dengan cukup baik dan update secara berkala. PT. Jasa Mulya Trans Gemilang telah memiliki tim khusus untuk mengelola Media Sosial Facebook dan Instagram. Selain Pemanfaatan Internet Marketing Gratis, PT. Jasa Mulya Trans Gemilang juga memanfaatkan Program Internet Marketing berbayar seperti Facebook Ads, Instagram Ads, dan Google Ads.

Selama ini Program Internet Marketing yang telah dilaksanakan di PT. Jasa Mulya Trans Gemilang mulai dari Website, Media Sosial hingga Program Internet Marketing berbayar Facebokk Ads, Instagram Ads dan Google Ads belum ada dilakukan pengukuran terkait dengan Efektivitas dari program Internet Marketing tersebut. Pengukuran untuk mengetahui Efektivitas sebuah Program Internet Marketing sangat diperlukan oleh sebuah perusahaan yang bergerak pada layanan transportasi seperti PT. Jasa Mulya Trans Gemilang.

Suatu usaha dapat dikatakan efektif apabila usaha itu mencapai tujuan yang ideal seperti yang diharapakan. Efektivitas pada Program Internet Marketing di PT. Jasa Mulya 
Trans Gemilang ini dapat dikatakan berhasil apabila usaha yang dilakukan mendapatkan hasil yang sesuai dengan tujuan yang hendak dicapai. Dan ukuran keberhasilan Program Internet Marketing tersebut, bisa didapatkan dengan melakukan Penelitian. Maka dari itu penulis tertarik untuk meneliti seberapa efektifkah pemanfaatan Internet Marketing yang diterapkan oleh PT. Jasa Mulya Trans Gemilang, Travel Angkutan Antar Jemput Alamat rute Pekanbaru Duri Dumai.

\section{Rumusan Masalah}

Pada Penjelasan Latar Belakang Masalah, maka didapatkan perumusan masalah sebagai berikut: 1) Bagaimanakah penerapan Internet Marketing di PT. Jasa Mulya Trans Gemilang, 2) Bagaimanakah efektivitas dari penerapan Internet Marketing di PT. Jasa Mulya Trans Gemilang.

\section{Tujuan Khusus Penelitian}

Tujuan dari penelitian ini adalah untuk mengetahui seberapa besar efektivitas penerapan Internet Marketing yang sudah diterapakan oleh pihak perusahaan PT. Jasa Mulya Trans Gemilang terhadap pertumbuhan pemesanan tiket Travel Pekanbaru Duri Dumai

\section{Urgensi Penelitian}

Penelitian ini nantinya akan menghasilkan sebuah produk yang sangat bermanfaat dan dapat dijadikan pertimbangan dalam mengambil sebuah keputusan strategi marketing pada era Marketing 4.0, di PT. Jasa Mulya Trans Gemilang. Produk dari penelitian ini juga dapat dimanfaatkan oleh masyarakat luas khususnya Usaha Mikro Kecil dan Menengah (UMKM) yang ada di kota Pekanbaru dalam hal penerapan Internet Marketing

\section{Tinjauan Pustaka Efektivitas}

"Efektivitas adalah sesuatu yang

menunjukkan taraf tercapainya suatu tujuan. Suatu usaha dapat dikatakan efektif apabila usaha itu mencapai tujuan secara ideal." Efektivitas menunjukkan keberhasilan dari segi tercapai atau tidaknya sasaran yang telah ditentukan. Hasil yang mendekati sasaran berarti tinggi tingkat efektivitasnya. Sebaliknya, hasil yang jauh dari sasaran maka kurang efektivitasnya[3].

Menurut Osborne dan Gaebler (1997: 389), dalam Alisman "efisiensi adalah ukuran berapa banyak biaya yang dikeluarkan untuk masing-masing unit output, sedangkan efektivitas adalah ukuran kualitas output itu." Ketika mengukur efisiensi, harus diketahui berapa banyak biaya yang harus ditanggung untuk mencapai suatu output tertentu. Ketika mengukur efektivitas harus diketahui apakah investasi tersebut dapat berguna. Efisiensi dan efektivitas merupakan hal penting, tetapi ketika organisasi publik mulai mengukur kinerja, seringkali hanya mengukur tingkat efisiensi saja. Pengertian efektivitas sesuai dengan Permendagri Nomor 59 Tahun 2007 adalah "merupakan pencapaian hasil program dengan target yang telah ditetapkan, yaitu dengan cara membandingkan keluaran dengan hasil." [4]

\section{Internet Marketing}

Internet Marketing adalah suatu kesatuan istilah yaitu pemasaran produk, baik barang maupun jasa secara online. Internet marketing mengacu pada strategi yang digunakan untuk memasarkan produk atau layanan online, strategi pemasarannya meliputi search engine optimization (SEO), search engine submission, copywriting yang mendorong pengunjung untuk aktif melakukan suatu tindakan, strategi desain website, promosi online, interaksi atau hubungan timbal balik (dialog), dan pemasaran dengan email[5].

Definisi sederhana dari Internet 
marketing atau yang biasa disebut juga online marketing atau webmarketing Menurut Wahyudi (2009) dalam Kuspuji Catur BW adalah "menjual barang atau jasa melalui media Internet. Online marketing dilakukan sebagai bagian dari bisnis offline. Konsumen akan lebih mengenalinya bila produk produknya terpampang dan dilengkapi dengan email yang bisa digunakan untuk melakukan pemesanan sebagaimana halnya fungsi katalog tercetak pada bisnis offline" [6].

Menurut Chaffey (2008) dalam Phamendyta Aldaning Azaria mengemukakan istilah "internet marketing cenderung mengacu pada perspektif tentang bagaimana internet dapat digunakan secara bersama-sama dengan media tradisional untuk mendapatkan dan memberikan layanan kepada pelanggan dengan dua cara. Pertama, meningkatkan efisiensi dalam fungsi pemasaran tradisional, kedua, teknologi e-marketing banyak mengubah strategi pemasaran. Alternatif istilah adalah e-marketing yang dapat dianggap memiliki lingkup yang lebih luas itu merujuk kepada penggunaan teknologi untuk mencapai tujuan pemasaran dan eksternal dan internal perspektif." [7].

\section{Marketing 4.0}

Marketing / Pemasaran menurut American Marketing Association adalah "proses perencanaan dan pelaksanaan rencana dalam hal penetapan harga, promosi dan distribusi ide-ide, barang-barang dan jasa untuk menciptakan pertukaran yang memuaskan tujuan-tujuan individual dan organisasi" [8].

Marketing 4.0 merupakan pendekatan pemasaran yang mengkombinasikan interaksi online dan interaksi offline antara perusahaan dengan pelanggan. Secara umum, Marketing 4.0 bisa dipahami seperti itu. Di era ekonomi digital, interaksi digital saja tidaklah cukup.
Kenyataannya, justru di saat dunia online berkembang, sentuhan offline menjadi titik diferensiasi yang kuat. Marketing 4.0 tidak hanya mengkombinasikan antara online dengan offline tetapi juga style dan substance. Artinya, merek bukan hanya mengutamakan citra yang bagus, tetapi juga konten yang sesuai dengan pelanggan atau menampilkan konten yang bagus dengan kemasan yang terbaru.[9].

Marketing 4.0 adalah pendekatan pemasaran yang menggabungkan interaksi online dan offline antara perusahaan dan pelanggan memadukan gaya dengan substansi dalam membangun merek, dan akhirnya melengkapi konektifitas mesin ke mesin dengan sentuhan manusia ke manusia untuk memperkuat keterlibatan pelanggan. Marketing 4.0 membantu pemasar beralih ke ekonomi digital, yang mendefenisikan ulang konsep dari pemasaran digital. Pemasaran digital dan pemasaran tradisional dimaksudkan untuk dipadukan dengan tujuan mendapatkan pembelaan pelangan[10].

\section{Penelitian Terdahulu}

Adapun Penelitian yang terdahulu yang relevan adalah Efektivitas Iklan Melalui Jejaring Sosial Sebagai Salah Satu Strategi Pemasaran Keripik Pedas Maicih [11]. Penelitian ini mengetahui seberapa besar efektivitas iklan melalui jejaring sosial, yang merupakan produk keripik pedas di PT. Maicih Inti Sinergi. Penelitian ini menggunakan teknik purposive sampling, yang terdiri dari 100 responden di Universitas Gunadarma. Variabel yang diteliti untuk mengukur efektivitas Jejaring Sosial adalah empati, persuasi, dampak, dan komunikasi. Rentang skala Likert yang digunakan dalam penelitian ini adalah 1 sampai 5. Hasil dari pengukuran dari beberapa dimensi EPIC diantaranya; dimensi empati sebesar 3,98, dimensi persuasi 
sebesar 3,99, dimensi dampak sebesar 3,93, dan dari dimensi komunikasi sebesar 3,90. Dari hasil pengukuran dimensi-dimensi EPIC diatas maka didapatkan nilai EPICrate 3,95. Nilai EPIC rate 3,95 tersebut menunjukkan iklan produk keripik pedas Maicih melalui jejaring sosial dinilai Sangat efektif.

Penelitian relevan kedua adalah Analisis Efektifitas Iklan Media Televisi Menggunakan EPIC Model (Studi Kasus Produk A Mild di Kota Langsa)[12]. Adapun tujuan penelitian ini untuk mengetahui efektivitas iklan A Mild Media Televisi dengan menggunakan EPIC Model. Iklan yang diteliti adalah Iklan A Mild media Televisi. Teknik penyebaran kuesioner pada Penelitian ini menggunakan purposive sampling dengan menyebar kuesioner kepada 96 responden di kota Langsa. Model yang digunakan untuk mengukur efektifitas dalam penelitian ini adalah Model EPIC yang teridiri dari 4 variabel diantarnya Empati, Persuasi, Dampak, Komunikasi. Dan skala Likert yang digunakan adalah skala 1-5. Dari total skor rataan pendapat respoden didapatkan Nilai EPICrate 3,99 yang teridiri dari dimensi Empati dengan hasil 4,00, dimensi persuasi sebesar 3,93, dimensi dampak sebesar 3,99, dan dari dimensi komunikasi sebesar 4,04. Nilai EPIC rate 3,99 tersebut menunjukkan bahwa secara keseluruhan dapat disimpulkan bahwa iklan A Mild berada pada skala efektif.

Penelitian terdahulu yang relevan ketiga adalah Analisis Efektivitas Iklan Media Sosial Sebagai Media Promosi (Studi Kasus : Instagram Taya.Id)[13]. Penelitian dilakukan dengan tujuan mengetahui efektivitas iklan social media TAYA.ID di instagram. Teknik pengambilan sampel menggunakan purposive sampling dengan kriteria responden yang sudah pernah membeli produk dari TAYA.ID dan responden yang telah mendapatkan informasi mengenai produk TAYA.ID. Penelitian EPIC Model untuk perhitungan efektivitas iklan yang terdiri dari empat dimensi yaitu empathy, persuasion, impact, dan communication. Rentang skala Likert yang digunakan adalah 1 sampai 4. Hasil dari penelitian ini membuktikan bahwa iklan social media TAYA.ID dinilai efektif dengan nilai EPIC Rate sebesar 2,777.

Dari beberapa penelitian terdahulu, penulis mendapatkan referensi dan ide baru yaitu bagaimana mengukur efektivitas sebuah pemanfaatan internet marketing yang telah di realisasikan oleh Layanan Jasa Trasportasi Antar Jemput Alamat untuk Rute Pekanbaru Duri Dumai di PT. Jasa Mulya Trans Gemilang. Penelitian ini menggunakan Model EPIC untuk mengukur tingkat Efektivitas sebuah Iklan Pemanfaatan Internet Marekting di PT. Jasa Mulya Trans Gemilang. Diharapakan nantinya hasil dari Penelitian ini dapat menjadi bahan pertimbangan bagi Pihak Perusahaan untuk mengambil langkah dan strategi terbaik dalam penerapan Internet Marketing kedepannya baik melalui Website, Media Sosial, Google Ads ataupun Offline Marketing di PT. Jasa Mulya Trans Gemilang.

\section{METODE}

Penelitian ini adalah penelitian kuantitatif yaitu penelitian yang lebih menekankan analisisnya pada numerikal (angka) yang diolah dengan metode statistika. Sebagian besar penelitian kuantitatif menggunakan intrumen pengumpulan data Kuersioner. Pada penelitian ini Kuesioner disebarkan disebarkan kepada setiap penumpang travel pekanbaru tujuan daerah Duri dan Kota Dumai. Teknik pengambilan sampel pada penelitian ini menggunakan systematic sampling yaitu sample yang diambil secara sistematis berurut tanggal $1-7$ setiap bulannya dan dilakukan selama tiga bulan berturut-turut.

Penelitian ini juga termasuk ke dalam 
jenis penelitian eksplanatif korelasional atau penelitian yang dimaksudkan untuk menjelaskan hubungan antar variabel dan membuat generalisasi. Dalam penelitian ini Efektivitas Internet Marketing terahadap pemesanan tiket travel pekanbaru duri dumai dapat diukur dengan menggunakan Model EPIC.

"Efektivitas iklan diukur dengan menggunakan Model EPIC[14]. Model EPIC terdiri dari empat dimensi berikut :

1) Dimensi empati, yang menginformasikan, apakah konsumen suka terhadap suatu bentuk komunikasi pemasaran yang ditawarkan dan menggambarkan bagaimana konsumen dapat hubungan antara suatu bentuk komunikasi pemasaran dengan pribadinya;

2) Dimensi persuasi, menginformasikan apa yang dapat diberikan dalam komunikasi pemasaran untuk menguatkan karakter suatu merek, sehingga produsen merek memperoleh pemahaman tentang dampak komunikasi pemasaran terhadap keinginan konsumen untuk membeli:

3) Dimensi dampak, menunjukkan, apakah sebuah merek dapat lebih baik, lebih menonjol dan lebih manarik dibandingkan merek lain pada kategori yang serupa;

4) Dimensi komunikasi, memberikan informasi tentang kemampuan konsumen dalam mengingat pesan utama yang disampaikan, pemahaman konsumen dan kekuatan kesan yang ditinggalkan pesan tersebut."

Dimensi tersebut nantinya akan diolah dengan mencari skor rata-rata dengan rumus sebagai berikut[14]:

$$
\bar{x}=\frac{\sum f i . w i}{\sum f i}
$$

Dimana:

$$
\begin{array}{ll}
\overline{\boldsymbol{x}} & =\text { rata-rata terbobot } \\
\text { fi } & =\text { frekuensi }
\end{array}
$$

langkah

selanjutnya adalah menggunakan rentang skala penilaian untuk menentukan posisi tanggapan responden

$$
R s=\frac{R(\text { bobot })}{M}
$$

Dimana :

$\mathrm{R}($ bobot $)=$ bobot terbesar - bobot terkecil

$\mathrm{M} \quad=$ banyaknya kategori berbobot

Langkah selanjutnya pun mencari skor EPIC Rate dengan rumus

$$
\text { EPIC Rate }=\frac{(x e m p+x \text { pers }+x \text { imp }+x \text { com })}{4}
$$

\section{HASIL}

\section{Karakteristik Responden}

Responden dalam dalam penelitian ini terdiri dari laki-laki (63\%) dan perempuan (37\%). Usia responden paling banyak adalah antara 16-24 tahun dengan presentase (30\%) dan diikuti usia atas 30-39 tahun dengan presentase (25\%) dan Usia 25-30 tahun dengan presentase $(22 \%)$. Berdasarkan karakteristik jenjang pendidikan responden. Jenjang pendidikan terbanyak berada pada tingkat SMA yaitu (50\%). Dan berdasarkan kategori Pekerjaan terbanyak adalah Wiraswasta sebesar (43\%) dan Pekerjaan lain-lain (20\%) dan Pekerjaan terbanyak ketiga adalah Mahasiswa sebesar (18\%).

Dari hasil penyebaran kuesioner yang telah dilaksanakan kepada pelanggan PT. Jasa Mulya Trans Gemilang untuk tujuan Duri sekitarnya dan Kota Dumai maka pernyataan yang ketiga pada lembar kuesioner yaitu "Iklan Jasa Mulya Travel di Internet sudah Memiliki Daya Tarik Tingggi”, 23 orang responden menjawab "Sangat Setuju" dengan presentase $(38,3 \%)$. Dan dari hasil penyebaran kuesioner yang telah dibagikan, peneliti juga mendapatkan informasi ada satu orang 
responden yang menyatakan "Sangat Tidak Setuju" dengan dengan pernyataan "Iklan Jasa Mulya Travel Internet lebih mampu menyampaikan pesan dari pada Iklan Travel lainya" dengan presentase $(1,6 \%)$.

\section{Skala Pengukuran Efektivitas}

Pengelolaan data model EPIC adalah menentukan tabulasi sederhana dan skor rataan yang kemudian dikonversikan ke rentang skala model EPIC. Cara menghitung skor rata-rata adalah sebagai berikut:

$$
\bar{x}=\frac{\sum f i \cdot w i}{\sum f i}
$$

Dimana:

$\overline{\boldsymbol{x}}=$ rata-rata terbobot

fi $=$ frekuensi

langkah selanjutnya adalah menggunakan rentang skala penilaian untuk menentukan posisi tanggapan responden

$$
\boldsymbol{R} \boldsymbol{s}=\frac{\boldsymbol{R}(\text { bobot })}{\boldsymbol{M}}
$$

Dimana :

$\mathrm{R}($ bobot $)=$ bobot terbesar - bobot terkecil

$\mathrm{M}$ = banyaknya kategori berbobot

Sehingga diperoleh posisi keputusan menurut hasil analisis EPIC seperti terlihat dalam gambar

Rentang skala Likert yang dipakai dalam penelitian ini adalah 1 sampai dengan 5, maka rentang skala penilaian yang didapat adalah :

$$
R s=\frac{5-1}{5}
$$

Sehingga posisi keputusan analisis EPIC Model adalah seperti gambar berikut :

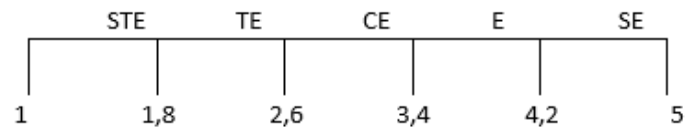

Gambar 1. Skala Likert 1-5

Keterangan :

$\begin{array}{ll}\text { STE } & \text { : Sangat Tidak Efektif } \\ \text { TE } & \text { : Tidak Efektif } \\ \text { CE } & : \text { Cukup Efektif } \\ \text { E } & \text { : Efektif } \\ \text { SE } & \text { : Sangat Efektif }\end{array}$

Hasil EPIC rate akan menggambarkan posisi efektivitas suatu produk dalam persepsi responden, sesuai dengan rentang skala yang telah di tentukan.

\section{Dimensi EPIC Model}

1. Dimensi Empathy

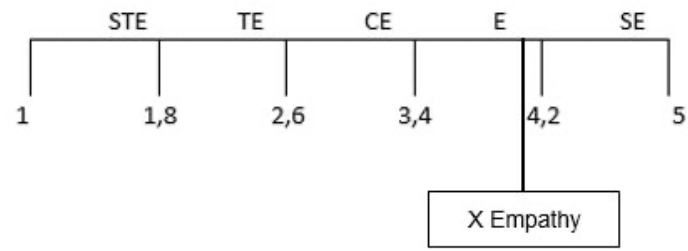

Gambar 2. Hasil Dimensi Empathy

Dari skala pengkuran Efektivitas pada dimensi Empathy yang terlihat pada gambar 2 diatas, maka Dimensi Emphaty memperoleh skor rataan terbesar yaitu sebesar 4,09. Nilai ini berada pada rentang skala dimana dimensi Empathy suatu iklan dinyatakan efektif dalam mempengaruhi pengguna di Internet. Hal ini dapat diartikan bahwa target responden terpengaruh oleh Promosi atau Iklan PT. Jasa Mulya Trans Gemilang melalui Website, Media Sosial, dan Iklan Google Ads yang sudah berjalan. Hasil pengukuran yang telah dilakukan untuk dimensi emphaty pada iklan PT. Jasa Mulya Trans Gemilang Rute Pekanbaru Duri Dumai melalui Internet dapat 
di interpretasikan ke dalam EPIC Model, dan nilai 4.09 tesebut masuk ke dalam kategori efektif.

2. Dimensi Persuasion

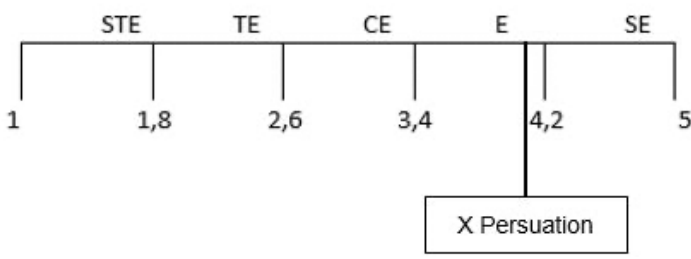

Gambar 3 Hasil Dimensi Persuasion

Dari skala pengkuran Efektivitas pada dimensi Persuasion yang terlihat pada gambar 3 diatas, maka Dimensi Persuasion memperoleh skor rataan terbesar yaitu sebesar 4,11. Nilai ini berada pada rentang skala dimana dimensi Persuasion suatu iklan dinyatakan efektif dalam mempengaruhi pengguna di Internet. Hal ini dapat diartikan bahwa target responden terpengaruh oleh Promosi atau Iklan PT. Jasa Mulya Trans Gemilang melalui Website, Media Sosial, dan Iklan Google Ads yang sudah berjalan. Hasil pengukuran yang telah dilakukan untuk dimensi Persuasion pada iklan PT. Jasa Mulya Trans Gemilang Rute Pekanbaru Duri Dumai melalui Internet dapat di interpretasikan ke dalam EPIC Model, dan nilai 4.11 tesebut masuk ke dalam kategori efektif.

\section{Dimensi Impact}

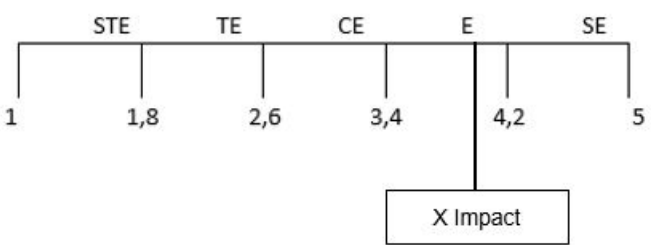

Gambar 4. Hasil Dimensi Impact

Dari skala pengkuran Efektivitas pada dimensi Persuasion yang terlihat pada gambar 4 diatas, maka Dimensi Impact memperoleh skor rataan terbesar yaitu sebesar 3,88. Nilai ini berada pada rentang skala dimana dimensi Impact suatu iklan dinyatakan efektif dalam mempengaruhi pengguna di Internet. Hal ini dapat diartikan bahwa target responden terpengaruh oleh Promosi atau Iklan PT. Jasa Mulya Trans Gemilang melalui Website, Media Sosial, dan Iklan Google Ads yang sudah berjalan. Hasil pengukuran yang telah dilakukan untuk dimensi Impact pada iklan PT. Jasa Mulya Trans Gemilang Rute Pekanbaru Duri Dumai melalui Internet dapat di interpretasikan ke dalam EPIC Model, dan nilai 3,88 tesebut masuk ke dalam kategori efektif.

4. Dimensi Communication

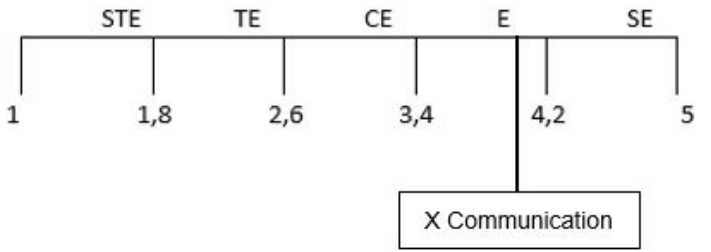

Gambar 5. Hasil Dimensi Communication

Dari skala pengkuran Efektivitas pada dimensi Persuasion yang terlihat pada gambar 5 diatas, maka Dimensi Communication memperoleh skor rataan terbesar yaitu sebesar 3,99. Nilai ini berada pada rentang skala dimana dimensi Communication suatu iklan dinyatakan efektif dalam mempengaruhi pengguna di Internet. Hal ini dapat diartikan bahwa target responden terpengaruh oleh Promosi atau Iklan PT. Jasa Mulya Trans Gemilang melalui Website, Media Sosial, dan Iklan Google Ads yang sudah berjalan. Hasil pengukuran yang telah dilakukan untuk dimensi Communication pada iklan PT. Jasa Mulya Trans Gemilang Rute Pekanbaru Duri Dumai melalui Internet dapat di interpretasikan ke dalam EPIC Model, dan nilai 3,99 tesebut masuk ke dalam kategori efektif. 


\section{EPIC Rate}

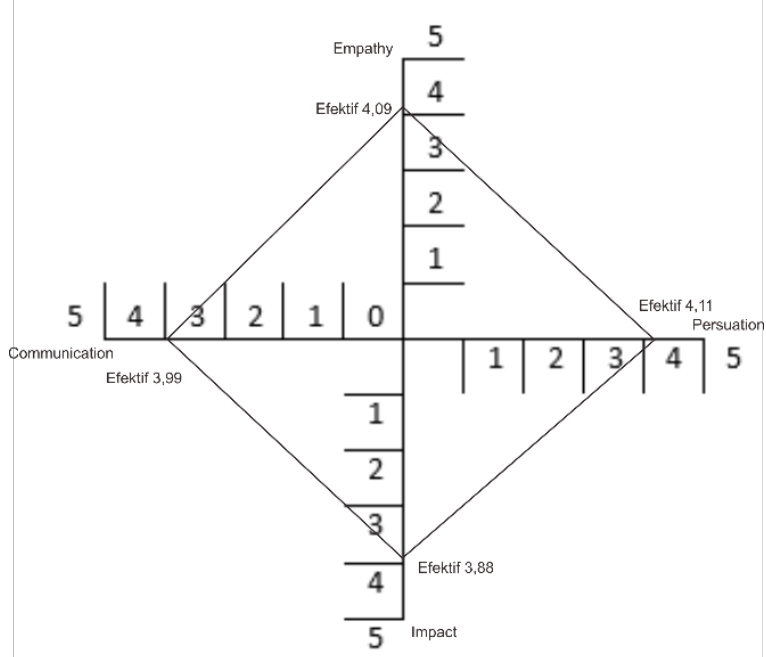

Gambar 6. Diagram EPIC Rate

Berdasarkan hasil pengukuran EPIC Rate yang terihat pada gambar 6 diatas, diketahui empat hasil dimensi EPIC yaitu pada Dimensi emphaty bernilai 4,09 yang berada pada skala efektif, Dimensi persuasion bernilai 4,11 juga berada pada skala efektif, Dimensi impact bernilai 3,88 juga termasuk pada skala Efketif, dan dimensi communication bernilai 3,99 juga berada dalam skala Efektif. Dari keempat skala tersebut Dimensi Persuation memiliki Skor tertinggi dengan skor 4,11. Dari empat skor dimensi EPIC tersebut yang terdiri dari Dimensi emphaty, Dimensi Persuation, Dimensi impact, dan Dimensi communication maka diketahui rata-rata atau hasil EPIC Rate-nya adalah 4,02, yang dapat di interpretasikan pada skala efektif. Artinya dari Hasil pengukuran yang telah dilakukan dalam penelitian ini untuk keempat Dimensi diatas menyatakan bahwa pemanfaatan Internet Marketing di PT. Jasa Mulya Trans Gemilang Rute Pekanbaru Duri Dumai melalui Internet sudah efektif.

\section{KESIMPULAN}

Penerapan internet marketing pada pemesaanan tiket travel pekanbaru duri dumai di PT. Jasa Mulya Trans Gemilang dengan menggunakan EPIC model dinilai Efektif. Hal tersebut dapat dilihat dari empat Dimensi EPIC yaitu emphaty bernilai 4,09 Persuasion 4,11, Impact 3,88 dan Communiaction 3,98. Dari empat dimensi EPIC tersebut maka didapat nilai EPICrate adalah 4,02. Penelitian ini terbatas pada pelanggan PT. Jasa Mulya Tras Gemilang dengan tujuan Pekanbaru Duri Dumai yang relatif telah mengenal media internet dengan baik.

Berdasarkan hasil penelitian yang sudah dilaksanakan, di PT. Jasa Mulya Trans Gemilang untuk mengukur efektifitas iklan di Internet, dengan Model EPIC hal ini tidak dapat menjamin bahwa kualitas layanan Jasa Transportasi di PT. Jasa Mulya Trans Gemilang sangat diminati oleh konsumen. Oleh sebab itu perlu adalanya pelitian lebih lanjut terkait degan efektifitas sebuah iklan PT. Jasa Mulya Trans Gemilang di Internet dengan menggunakan beberapa metode lain yang sudah teruji dalam karya ilmiah lainya. Dan PT. Jasa Mulya Trans Gemilang perlu melakukan kreatifitas dan inovasi baru terhadap layanannya agar dapat meningkatkan kepercayaan masyarakat terhadap pelayanan jasa Transportasi Travel dari PT. Jasa Mulya Trans Gemilang khususnya untuk Rute Pekanbaru Duri Dumai.

Dilihat dari responden dalam pelaksanaan penelitian ini, sudah memiliki respon yang baik terhadap iklan Internet Marketing PT. Jasa Mulya Trans Gemilang di Internet, disamping kualitas iklan, PT. Jasa Mulya Trans Gemilang perlu meningkatkan kualitas produk layanan agar konsumen menjadi loyal nyaman dan bertahan menggunakan Jasa Transportasi travel ini khususnya Rute Pekanbaru Duri Dumai.

\section{DAFTAR PUSTAKA}

[1] A. Savitri, Revolusi Industri 4.0 : Mengubah Tantangan Menjadi Peluang 
di Era Disrupsi 4.0. Yogyakarta: Genesis, 2019.

[2] R. K. Muljono, Digital Marketing Concept. 2018.

[3] S. Asiah, "Efektivitas Kinerja Guru," Ef. KInerja Guru, vol. 4, no. 2, pp. 111, 2016.

[4] Alisman, "Analisis Efektivitas Dan Efisiensi Manajemen," J. Ekon. dan Kebijak. Publik Indones., 2014.

[5] B. Musty, "Membangun Branding Melalui Pengembangan Internet Marketing Dalam Sektor Pendidikan," vol. 1, no. 2, pp. 1-6, 2012.

[6] K. Catur Bagus Wicaksono, "Mengukur Efektivitas Social Media Bagi Perusahaan," Binus Bus. Rev., 2013.

[7] P. Azaria, "Pengaruh Internet Marketing Terhadap Pembentukan Word Of Mouth Dan Efektivitas Iklan Dalam Meningkatkan Brand Awareness (Studi pada Follower Akun Twitter Pocari Sweat di Jejaring Sosial Twitter)," $J$. Adm. Bisnis S1 Univ. Brawijaya, vol. 13, no. 1, p. 83875, 2014.

[8] A. M. Afrilia, "Digital Marketing Sebagai Strategi Komunikasi Pemasaran 'Waroenk Ora Umum' Dalam Meningkatkan Jumlah Konsumen," J. Ris. Komun., 2018.

[9] A. D. Mukhoyaroh and R. Susilawati, "Marketing 4.0 Untuk Usaha Mikro Tas Tali Kur Desa Mojongapit Kecamatan Jombang Kabupaten Jombang Jawa Timur," J. Terap. Abdimas, 2019.

[10] P. Kotler, H. Kartajaya, and D. H. Hooi, "Marketing 4.0: Moving From Traditional To Digital," in Asian Competitors, 2019.

[11] B. Riyantoro, "Efektivitas Iklan Melalui Jejaring Sosial Sebagai," Proceeding PESAT (Psikologi, Ekon. Sastra, Arsit. Tek. Sipil), 2013.

[12] D. R. Indah and Z. Maulida, "Analisis Efektivitas Iklan Media Televisi Mengunakan EPIC Model (Studi Kasus Produk A Mild di Kota Langsa)," $J$. Penelit. Ekon. Akunt., vol. 1, no. 2, pp. 137-149, 2017.

[13] A. T. Wijaya, H. Amani, and W.
Tripiawan, "Analysis effectiveness of social media ad as promotional media ( study case: instagram taya. Id ) Abstrak Kata Kunci: Efektivitas Iklan dan EPIC Model A," vol. 5, no. 1, pp. 1123-1130, 2018.

[14] D. C. Durianto and Liana, Inovasi pasar dengan iklan yang efektif. Jakarta: Gramedia, 2003. 